\title{
Marxism Theory in Indonesian Literatures
}

\author{
Kundharu Saddhono ${ }^{1}$, Muhammad Rohmadi ${ }^{1}$, Panji Kuncoro $\operatorname{Hadi}^{2}$, Ulinnuha Madyananda ${ }^{2}$, \\ Chafit Ulya ${ }^{1}$, Memet Sudaryanto ${ }^{1}$, Raheni Suhita ${ }^{1}$, Atikah Anindyarini ${ }^{1}$, Arif Setyawan ${ }^{1}$, Laili \\ Etika Rahmawati ${ }^{3}$ \\ ${ }^{1}$ Universitas Sebelas Maret \\ ${ }^{2}$ Universitas PGRI Madiun, Jawa Timur \\ ${ }^{3}$ Universitas Muhammadiyah Surakarta \\ kundharu_s@staff.uns.ac.id
}

\begin{abstract}
This study aimed to prove and explain the existence of Marxism theory in Indonesian literature, namely in one poem of anthology under the title Nyanyian Akar Rumput written by Wiji Thukul. Hermeneutic readings by Paul Ricoeur was done to prove the hypothesis. This study was a literary research that could be included as descriptive qualitative research using content analysis method. Content analysis method as mentioned above used four (4) readings or methodological steps which were: first, objectivation through structure; second, distortions through writing; third, distortion through the world of texts; and fourth, appropriation or self-understanding. Those four methodologies could be rendered succinctly that the first step was to determine the text using structural analysis, then the second step was to interpret symbolic codes within biography of the author or factors related to the author and last step was to relate to things outside that involve the other disciplines which is primarily relating to the doctrine or view of Marxism philosophy. After hermeneutic reading, it could be concluded that Nyanyian Akar Rumput, poetry written by Wiji Thukul which was collected in a book with the same title, wa proved to contain Marxism theory.
\end{abstract}

Keywords: Hermeneutic, Paul Ricoeur, Nyanyian Akar Rumput, Wiji Thukul, Marxism

1 INTRODUCTION

[RETRACTED]

This article was retracted at the request of the authors due to sensitive content in the reported case. 